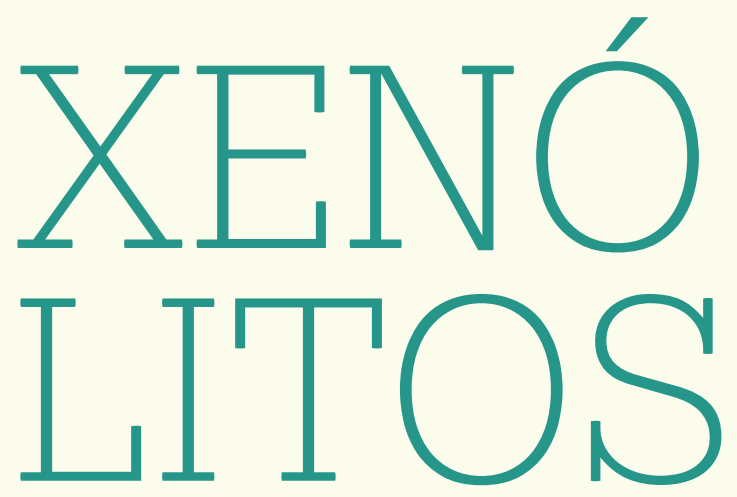

Fragmento de rocha preexistente, envolvido numa rocha magmática. 


\section{UMA NOITE \\ E OUTROS \\ POEMAS DE JOSÉ ASUNCIÓN SILVA ${ }^{1}$}

- TRADUÇÃO E SELEÇÃO DE GEYLSON ALVES

[1] Autor colombiano modernista (1865-1896). Desempenhou um papel relevante na poesia colombiana do século XIX, sendo um dos primeiros a transgredir o discurso clássico do metro. É considerado um dos fundadores do movimento modernista hispano-americano junto a poetas como José Martí, Rubén Darío e Salvador Díaz Mirón. Sua obra possui ressonâncias do romantismo e versa de forma geral sobre a melancolia. 


\section{UNA NOCHE}

Una noche

Una noche toda llena de perfumes, de murmullos y de músicas de älas,

Una noche

En que ardían en la sombra nupcial y húmeda, las luciérnagas fantásticas,

A mi lado, lentamente, contra mí ceñida, toda,

Muda y pálida

Como si un presentimiento de amarguras infinitas,

Hasta el fondo más secreto de tus fibras te agitara,

Por la senda que atraviesa la llanura florecida

Caminabas,

Y la luna llena

Por los cielos azulosos, infinitos y profundos esparcía su luz blanca,

$Y$ tu sombra

Fina y lánguida,

$Y$ mi sombra

Por los rayos de la luna proyectada

Sobre las arenas tristes

De la senda se juntaban

Y eran una

Y eran una

Y eran una sola sombra larga!

Y eran una sola sombra larga!

Y eran una sola sombra larga!

Esta noche

Solo, el alma

Llena de las infinitas amarguras y agonías de tu muerte,

Separado de ti misma, por la sombra, por el tiempo y la distancia,

Por el infinito negro,

Donde nuestra voz no alcanza,

Solo y mudo

Por la senda caminaba,

Y se oían los ladridos de los perros a la luna,

A la luna pálida

$Y$ el chillido

De las ranas,

Sentí frío, era el frío que tenían en la alcoba 
Tus mejillas y tus sienes y tus manos adoradas,

Entre las blancuras níveas

De las mortüorias sábanas!

Era el frío del sepulcro, era el frío de la muerte,

Era el frío de la nada...

Y mi sombra

Por los rayos de la luna proyectada,

Iba sola,

Iba sola

¡Iba sola por la estepa solitaria!

$Y$ tu sombra esbelta y ágil

Fina y lánguida,

Como en esa noche tibia de la muerta primavera,

Como en esa noche llena de perfumes, de murmullos y de músicas de alas,

Se acercó y marchó con ella,

Se acercó y marchó con ella,

Se acercó y marchó con ella... iOh las sombras enlazadas!

iOh las sombras que se buscan y se juntan en las noches de negruras y de lágrimas!... 


\section{UMA NOITE}

Uma noite

Uma noite toda cheia de perfumes, de murmúrios e de músicas de asas,

Uma noite

Em que ardiam na sombra nupcial e úmida, os vagalumes fantásticos, A meu lado, lentamente, contra mim cingida, toda,

Muda e pálida

Como se um pressentimento de amarguras infinitas, Até o fundo mais secreto de tuas fibras te agitara,

Pela senda que atravessa a planície florescida

Caminhavas,

E a lua cheia

Pelos céus azulados, infinitos e profundos espalhava sua luz branca,

E tua sombra

Fina e lânguida,

E minha sombra

Pelos raios da lua projetada

Sobre as areias tristes

Da senda se juntavam

E eram uma

E eram uma

E eram uma só sombra longa!

E eram uma só sombra longa!

E eram uma só sombra longa!

Esta noite

Só, a alma

Cheia das infinitas amarguras e agonias de tua morte,

Separado de ti mesma, pela sombra, pelo tempo e pela distância,

Pelo infinito negro,

Onde nossa voz não alcança,

Só e mudo

Pela senda caminhava,

E se ouviam os latidos dos cães à lua,

À lua pálida

E o coaxar

Das rãs,

Senti frio, era o frio que tinham no quarto 
Tuas bochechas e tuas têmporas e tuas mãos adoradas,

Entre as brancuras níveas

Dos mortuários lençóis!

Era o frio do sepulcro, era o frio da morte,

Era o frio do nada...

E minha sombra

Pelos raios da lua projetada,

Ia só,

Ia só,

Ia só pela estepe solitária!

E tua sombra esbelta e ágil

Fina e lânguida,

Como nessa noite tíbia da morta primavera,

Como nessa noite cheia de perfumes, de murmúrios e de músicas de asas, Aproximou-se e andou com ela,

Aproximou-se e andou com ela,

Aproximou-se e andou com ela... Oh as sombras enlaçadas!

Oh as sombras que se buscam e se juntam nas noites de negruras e de lágrimas!... 


\section{LA MUSA ETERNA}

Al poeta A. de W.

Cuando de tus estrofas sonoras

$Y$ en tus bellas imágenes,

En los años o siglos venideros

Ya no se acuerde nadie,

Cuando estén olvidados para siempre

Tus versos admirables,

Cuando algún sabio con trabajo inmenso

Descubra a Núñez de Arce,

Hablarás con las almas soñadoras,

El rumor de los valles

Llevado por los vientos campesinos

Al expirar la tarde.

Aún tendrá sus acentos misteriosos

La voz de los follajes,

El ruido sonoro de las olas

$Y$ el murmullo del viento en los juncales.

Nacerán los idilios

Entre musgo, a la sombra de los árboles,

Brotarán nuevas fuentes de poesía

En lo bello y lo grande

Y quedará el poema

De amor puro y suave. 


\section{A MUSA ETERNA}

Ao poeta A. de W.

Quando de tuas estrofes sonoras

$\mathrm{E}$ em tuas belas imagens,

Nos anos ou séculos vindouros

Ninguém mais se recordar,

Quando estiverem esquecidos para sempre

Teus versos admiráveis,

Quando algum sábio com trabalho imenso

Descobrir Núñez de Arce,

Falarás com as almas sonhadoras,

O rumor dos vales

Levado pelos ventos campestres

Ao expirar da tarde.

Ainda terá seus acentos misteriosos

A voz das folhagens,

$O$ ruído sonoro das ondas

$\mathrm{E}$ o murmúrio do vento nos juncais.

Nascerão os idílios

Entre musgo, à sombra das árvores,

Brotarão novas fontes de poesia

No belo e grande

E ficará o poema

De amor puro e suave. 


\section{MELANCOLÍA}

De todo lo velado,

Tenue, lejana y misteriosa surge

Vaga melancolía

Que del ideal al cielo nos conduce.

He mirado reflejos de ese cielo

En la brillante lumbre

Con que ahuyenta las sombras, la mirada

De sus ojos azules.

Leve cadena de oro

Que una alma a otra alma con sus hilos une

Oculta simpatía,

Que en lo profundo de lo ignoto bulle,

$Y$ que en las realidades de la vida

Se pierde y se consume

Cual se pierde una gota de rocío

Sobre las yerbas que el sepulcro cubren. 


\section{MELANCOLIA}

De todo o velado,

Tênue, longínqua e misteriosa surge

Vaga melancolia

Que do ideal ao céu nos conduz.

Mirei reflexos desse céu

No brilhante lume

Com que afugentas as sombras, a mirada

De seus olhos azuis.

Leve corrente de ouro

Que uma alma a outra alma com seus fios une

Oculta simpatia,

Que no profundo do ignoto ebule,

E que nas realidades da vida

Perde-se e consome-se

Como se perde uma gota de rocio

Sobre as ervas que o sepulcro cobrem. 


\section{EL MAL DEL SIGLO}

El paciente:

Doctor, un desaliento de la vida

Que en lo íntimo de mí se arraiga y nace,

El mal del siglo... el mismo mal de Werther,

De Rolla, de Manfredo y de Leopardi.

Un cansancio de todo, un absoluto

Desprecio por lo humano... un incesante

Renegar de lo vil de la existencia

Digno de mi maestro Schopenhauer;

Un malestar profundo que se aumenta

Con todas las torturas del análisis...

El médico:

- Eso es cuestión de régimen: camine De mañanita; duerma largo, báñese; Beba bien; coma bien; cuídese mucho, ¡Lo que usted tiene es hambre!... 


\section{O MAL DO SÉCULO}

O paciente:

Doutor, um desalento da vida

Que no íntimo de mim se arraiga e nasce, O mal do século... o mesmo mal de Werther, De Rolla, de Manfredo e de Leopardi.

Um cansaço de tudo, um absoluto

Desprezo pelo humano... um incessante

Renegar do vil da existência

Digno de meu mestre Schopenhauer;

Um mal-estar profundo que aumenta

Com todas as torturas da análise...

O médico:

- Isso é questão de regime: caminhe

De manhãzinha; durma bastante, tome banho;

Beba muito líquido; coma bem; cuide-se muito,

$\mathrm{O}$ que você tem é fome!... 
GEYLSON ALVES - É licenciado em Letras pela Universidade Federal de Campina Grande e pós-graduando em Tradução de Espanhol pela Universidade Estácio de Sá.

\section{REFERÊNCIAS}

SILVA, José Asunción. "El mal del siglo”. In: Obra Completa. Coord. Héctor H.

Orjuela. Ed. crítica. 2. ed. Madrid: ALLCA XX, 1996. p. 74.

. "La musa eterna”. In: Obra Completa. Coord. Héctor H.

Orjuela. Ed. crítica. 2. ed. Madrid: ALLCA XX, 1996. p. 205.

“Melancolía”. In: Obra Completa. Coord. Héctor H.

Orjuela. Ed. crítica. 2. ed. Madrid: ALLCA XX, 1996. p. 167.

. “Una noche”. In: Obra Completa. Coord. Héctor H.

Orjuela. Ed. crítica. 2. ed. Madrid: ALLCA XX, 1996. p. 32-33. 